\title{
VIENAN-KARJALAN JOIKUSÄVELMISTÄ (1916)
}

Vienan-karjalaisen joiun käsittämiseen ei riitä Lapin samannimisen laulunlajin tunteminen. Etenkin sävelmät näyttävät ensi silmäyksellä olevan kokonaan vailla sukulaisuutta. Fil. toht. A. Launis on osoittanut, että pentatonisuus on jälkimmäisen joiun tunnusmerkillinen piirre, samaten huomaamme, tarkastellessamme L:n keräämää ja julkaisemaa sävelkokoelmaa "Lappische Juoigosmelodien" että sen toisena yleispiirteenä on suppea muotorakenne. Vienan-karjalainen joiku edustaa kehittyneempää kantaa. Tärkein niistä harvoista vertauskohdista, joita molemmista mainituista joiuista on löydettävissä, on säkeiden välinen refrängi täyteäännähdyksineen. Vienan-karjalaisessa joiussa sitä nimitetään "hehetykseksi", ehkä siitä syystä, että korusävelkuvioitten laulannassa käytetään useimmiten tavuja he-he, siis kuten Suomen laulukin tekee. Hehetyksessä ilmenevät yleensä sävelmän luonteenomaisimmat käänteet, ja siitä tunnnetaan kussakin kylässä, ketä nuorta miestä kulloinkin joiutaan. Wagnerin nimitystä käyttääksemme on hehetys joiunnan johtoaihe. Lappalaisjoikuja säveltää "nuotin" muille-

Esitelmä Musiikkitieteellisen seuran kokouksessa maaliskuussa 1916. Julkaistu Uudessa sävelettäressä 56, 1916, s. $118-119$. 
kin ilmiöille kuin ihmiselle, mm. eräille eläimille, joiden ääniä joikauksessa koetetaan matkia, vienan-karjalainen rajoittuu ihmiselämään, käsitellen mieluimmin nuorten rakkausseikkoja. Juuri tämän eepillisen, ahtaammin määriteltynä satiirisen yleisluonteensa kautta eroaa viimemainittu joiku lyyrillisestä itkuvirrestä. Vertaamalla seuraavia joiun ja itkuvirren fonografoituja näytteitä toisiinsa, käy päättäminen sekä sävelmien että runojen rakenteessa piilevä läheinen sukulaisuus; itkuvirren sävelmä vain on vailla joiun refrängiä. Käymättä tässä yhteydessä yksityiskohtaiseen analyysiin, toteamme, että puheenaoleva joiku on suomalaisella alueella nykyään tavattavista laulunlajeista itkuvirren ohella ainoa, jossa improvisatsiolla on tärkeä sija ja jonka refrängin käytölle ja aihepiirille löydämme vertauskohtia kaukaisten luonnonkansain alkeellisesta runoudesta ja musiikista.
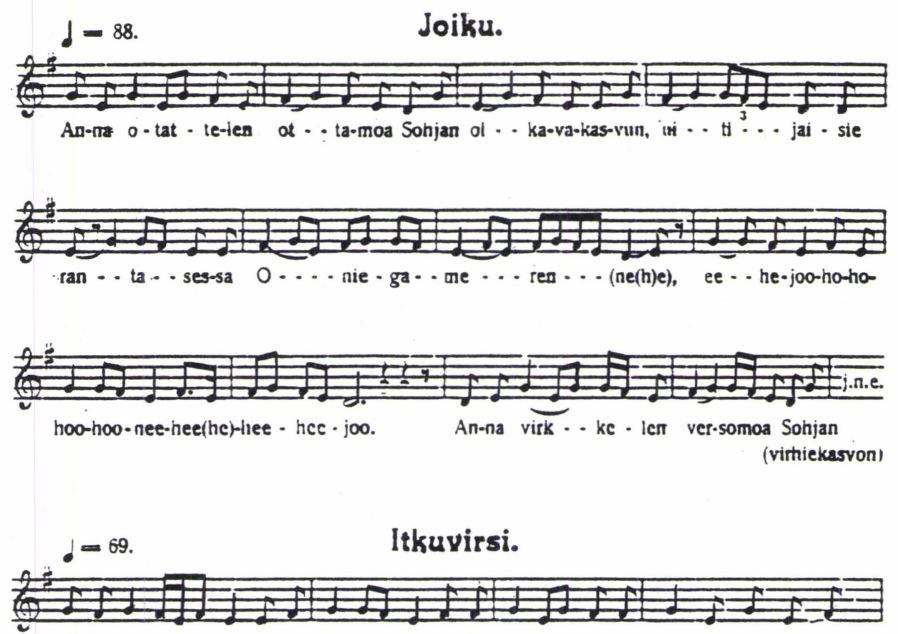

Mi-tä tuu-vis - hy-vă-sen' tu-let - to-mil-la ai-ka - sil-la e - sis - să tun-non-
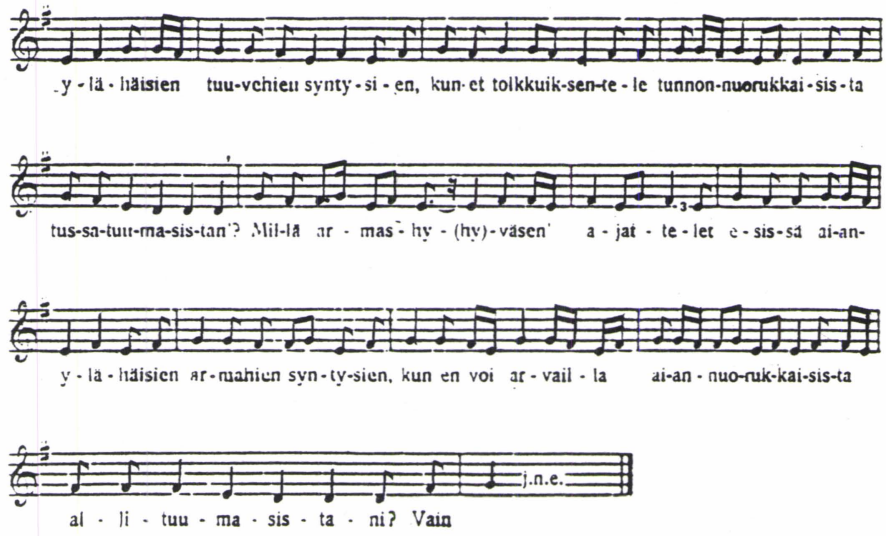